\title{
Therapeutic Hypothermia in Asphyxiated Newborn: Its Applicability, Feasibility and Accessibility in Developing Country India: A Long Way to Go
}

Deepak Sharma*, Aakash Pandita and Chetan Kumar

Department of Neonatology, Fernandez Hospital, Hyderabad, India

*Corresponding author: Deepak Sharma, Department of Neonatology, Fernandez Hospital, Hyderabad, India, Tel: +919462270002; E-mail: dr.deepak.rohtak@gmail.com

Rec date: 12 Oct 2014; Acc date: 15 Oct 2014; Pub date: 17 Oct 2014

Copyright: (c) 2014 Sharma D, et al. This is an open-access article distributed under the terms of the Creative Commons Attribution License, which permits unrestricted use, distribution, and reproduction in any medium, provided the original author and source are credited.

\section{Introduction}

About four million newborn children die annually. Almost one quarter $(23 \%)$ of these deaths are caused by perinatal asphyxia, most of them in developing countries [1-3]. The clinical signs following perinatal asphyxia have been called hypoxic ischemic encephalopathy (HIE). HIE occurs in 1 to 3 per 1,000 live births in high income countries, and up to 20 per 1,000 live births in low and middle-income countries [4]. In addition, perinatal asphyxia causes an even greater number of children to develop neurological sequels. The clinical signs following perinatal asphyxia have been called hypoxic ischemic encephalopathy (HIE) [5,6]. The onset of the asphyxial event leading to HIE could start antenatally or close to/during birth and the reported incidence of asphyxia with antenatal vs. perinatal onset differs substantially between studies $[7,8]$.

Therapeutic hypothermia has become the standard of care for asphyxiated term and near term newborn infants. American Academy of Pediatrics (AAP) committee on fetus and newborn recommends therapeutic hypothermia to be started within 6 hours of birth and continued for 72 hours followed by gradual rewarming [9]. In the developed countries therapeutic hypothermia has become standard of care and easily assessable to asphyxiated newborns but low and middle income developing countries like ours is still in primary phase with only few institute and tertiary care hospital providing therapeutic hypothermia. The cooling devices can be high tech like blanketrol, tecotherm (Figures 1 and 2), MTRE criticool, Cool cap or low tech like natural cooling, water bottles, fans, gels packs and phase changing mattresses [10]. Hypothermia acts through multiple mechanism to decrease the brain injury and effects primary phase, latent phase and secondary phase of brain injury and reduce penumbral brain injury taking place due to free radical generation $[11,12]$.

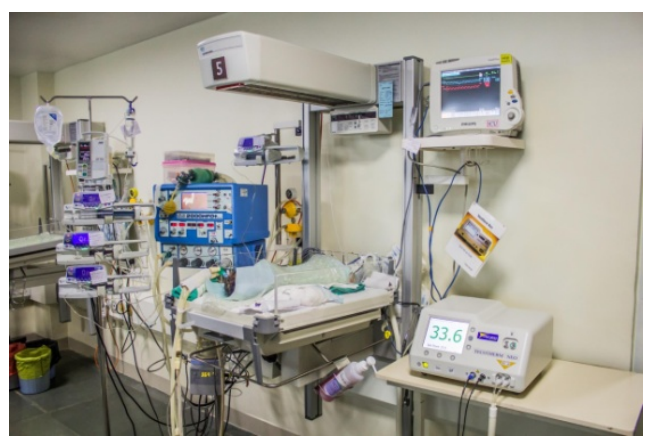

Figure 1: High tech cooling devices

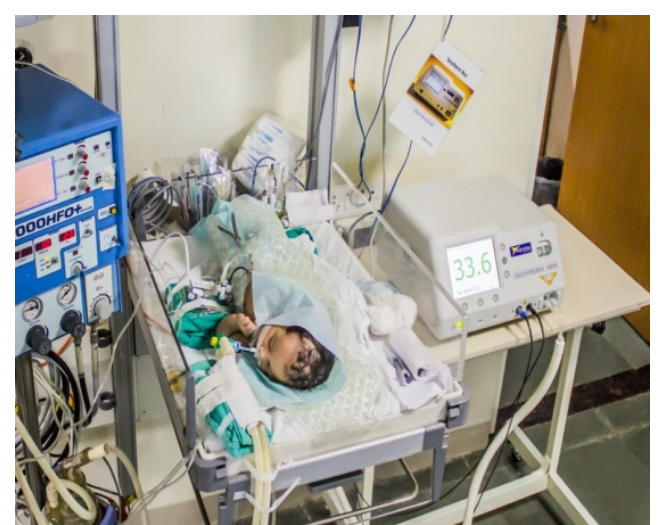

Figure 2: High tech cooling device

There are few studies conducted in India on therapeutic hypothermia in which the researchers have used different methods for cooling like gel packs. The limitations of these studies includes very small number of neonates in all the groups and the majority of the trials lacked long term follow-up of neurodevelopmental outcome (Table 1).

The problems of effective implementation of therapeutic hypothermia in India and other low-middle income groups are many which include:

- The financial aspect is very important as the high technology machines comes in millions of Indian rupees which every hospital can't afford which leads to avoidance of buying these machines for providing therapeutic hypothermia to asphyxiated neonates

- In the developing countries like ours there are very few well established level three care NICU which can provide hypothermia as providing hypothermia requires multiple other things like multi-parametric monitors, blood gas analysis machine, ventilators, EEG machine which puts great economic burden to the health care facilities.

- There is lack/shortage of well-trained pediatricians and nursing staff for hypothermia applications and its associated complication management.

- Failure to get the relevant history of perinatal asphyxia in the newborns and the treating pediatricians may not be able to identify the hypoxic encephalopathy.

- In resource restricted countries like ours, neurological damage due to perinatal asphyxia may be an add on because of associated maternal malnutrition, intra-uterine growth restriction of fetus, 
Citation: Sharma D, Pandita A, Kumar C (2014) Therapeutic Hypothermia in Asphyxiated Newborn: Its Applicability, Feasibility and Accessibility in Developing Country India: A Long Way to Go. J Neonatal Biol 3: E-111. doi:10.4172/2167-0897.1000E-111

Page 2 of 3

obstructed labor and poor or suboptimal obstetric / neonatal care at the time of delivery.

- As the incidence of intrauterine growth retarded newborns (IUGR) is very high in low-middle income countries and the response of these IUGR newborns or small for gestational age may be different from there counterpart appropriate for gestational age newborns.
- As in the low middle income group countries majority of the deliveries happen outside the hospital either at home or primary health care which don't have adequate resuscitation and referral facilities hence late referral of these asphyxiated newborns may reduce the usefulness of cooling once the therapeutic window has elapsed.

\begin{tabular}{|c|c|c|c|c|c|}
\hline SI. no & Investigations & Type of hypothermia & $\begin{array}{l}\text { Device used for } \\
\text { hypothermia }\end{array}$ & No. of newborns & Results \\
\hline 1 & $\begin{array}{l}\text { Bharadwaj et al. } \\
\text { (13) }\end{array}$ & Whole body cooling & Frozen gel packs & 62 & $\begin{array}{l}\text { TH group showed significant reduction in the } \\
\text { combined rate of death or developmental delay at } 6 \\
\text { months of age by } 21 \% \text { ( } 8.1 \% \text { in the TH group vs. } 29 \% \\
\text { in the control, RR } 0.28,95 \% \mathrm{Cl}: 0.11-0.70 ; p=0.003 \text { ). }\end{array}$ \\
\hline 2 & Joy et al. (14) & Whole body cooling & Frozen gel packs & 58 & $\begin{array}{l}\text { After } 72 \mathrm{~h} \text { of TH, TAS (total antioxidant status) was } \\
\text { significantly higher }(p=<0.001)(761.69 \pm 114.01 \text { vs. } \\
684.16 \pm 88.86) \text { and malondialdehyde (MDA) was } \\
\text { significantly lower }(p=<0.001) \text { in TH group (1.73 } \pm \\
0.66 \text { vs. } 5.2 \pm 1.06) \text {. Risk of developing deficit was } \\
\text { lower }(p<0.001) \text { in TH group with relative risk of } 0.49 \\
\text { and } 95 \% \text { confidence interval: } 0.29-0.68 \text {. }\end{array}$ \\
\hline 3 & Gane et al. (15) & Whole body cooling & Frozen gel packs & 60 & $\begin{array}{l}\text { After } 72 \mathrm{~h} \text {, the hypothermia group showed lower olive } \\
\text { tail moment }(12.88 \pm 2.14) \text { than the control group } \\
(22.16 \pm 5.26)(p<0.001) \text {. } 8 \text {-HDG }(8 \text { hydroxy } 2- \\
\text { deoxyguanosine) levels were significantly increased } \\
\text { in the control group }(1252.87 \pm 357.07) \text { as compared } \\
\text { to the hypothermia group }(757.03 \pm 198.49) \text { ( } p< \\
0.001) \text {. Neurodevelopmental assessment at } 12 \\
\text { months showed significantly higher motor and mental } \\
\text { developmental quotient in the hypothermia group than } \\
\text { control. }\end{array}$ \\
\hline 4 & Thomas et al. (16) & Whole body cooling & Frozen gel packs & 20 & $\begin{array}{l}\text { The mean rectal temperature during cooling was } 32.9 \\
\pm 0.11^{\circ} \mathrm{C} \text {. The target temperature could be maintained } \\
\text { for } 72 \text { hours without difficulty in all babies. }\end{array}$ \\
\hline 5 & Thomas et al. (17) & Whole body cooling & Frozen gel packs & 40 & $\begin{array}{l}\text { Skin temperature cannot be used instead of rectal } \\
\text { temperaturewhen practicing } \mathrm{TH} \text { for HIE }\end{array}$ \\
\hline 6 & Thayyail et al. (18) & Whole body cooling & Not specified & 17 & $\begin{array}{l}\text { TH did not reduce the brain injury apparent on MRI } \\
\text { imaging }\end{array}$ \\
\hline 7 & Bhat et al. (19) & Whole body cooling & Not specified & 20 & $\begin{array}{l}\text { Neonates treated by TH less likely to have abnormal } \\
\text { neurologicalexamination at discharge }(p<0.001) \text {. }\end{array}$ \\
\hline
\end{tabular}

Table 1: Table showing various therapeutic hypothermia studies conducted in India

- In developing countries perinatal asphyxia and neonatal sepsis may be co-existent and it may be sometimes impossible to differentiate them, and as therapeutic hypothermia decrease the resistance power and neutrophil function which may paradoxically increase the neonatal mortality [1].

- Un-controlled and accidental hypothermia is observed in many asphyxiated newborns in developing countries due to a number of factors including lack of proper transport facility, home birth, lack of basic neonatal care and overhead radiant warmers

- Therapeutic hypothermia window is very short(less than 6 hours), hence timely referral becomes difficult as there is lack of transport or adequate referral facilities in the low middle income group countries.

Therapeutic hypothermia is the call of hour as this has proved that therapeutic hypothermia results in a statistically significant and clinically important reduction in the combined outcome of mortality or major neuro developmental disability to 18 months of age. The
Cochrane database recommends institution of therapeutic hypothermia in term and late preterm infants with moderate-to-severe hypoxic ischaemic encephalopathy within six hours of age [20]. The developing countries have to go long way for the implementation of hypothermia so that every asphyxiated newborn gets therapeutic hypothermia in these low-middle income groups of countries [21]. There is also need to get cheap hypothermia devices which can are safe, affordable, maintains constant rectal temperature, less adverse effects, have adequate safety mechanism [22,23].

\section{References}

1. Pauliah SS, Shankaran S, Wade A, Cady EB, Thayyil S (2013) Therapeutic hypothermia for neonatal encephalopathy in low- and middle-income countries: a systematic review and meta-analysis. PLoS One 8: e58834.

2. Indian National Neonatal Perinatal Database (2005) National Neonatology forum 2002-2003.

3. Indian Institute of Population Studies (2000) National Family Health Survey (NFHS-2) 1998-99. Mumbai. 
Citation: Sharma D, Pandita A, Kumar C (2014) Therapeutic Hypothermia in Asphyxiated Newborn: Its Applicability, Feasibility and Accessibility in Developing Country India: A Long Way to Go. J Neonatal Biol 3: E-111. doi:10.4172/2167-0897.1000E-111

Page 3 of 3

4. Azra Haider B, Bhutta ZA (2006) Birth asphyxia in developing countries: current status and public health implications. Curr Probl Pediatr Adolesc Health Care 36: 178-188.

5. Phelan JP, Martin GI, Korst LM (2005) Birth asphyxia and cerebral palsy. Clin Perinatol 32: 61-76, vi.

6. Lawn JE, Cousens S, Zupan J; Lancet Neonatal Survival Steering Team (2005) 4 million neonatal deaths: when? Where? Why? Lancet 365: 891-900.

7. Badawi N, Kurinczuk JJ, Keogh JM, Alessandri LM (1998) Antepartum risk factors for newborn encephalopathy. BMJ 317: 1549-1553.

8. Cowan F, Rutherford M, Groenendaal F, Eken P, Mercuri E, et al. (2003) Origin and timing of brain lesions in term infants with neonatal encephalopathy. Lancet 361: 736-742.

9. Committee on Fetus and Newborn, Papile LA, Baley JE, Benitz W, Cummings J, et al. (2014) Hypothermia and neonatal encephalopathy. Pediatrics 133: 1146-1150.

10. Robertson NJ, Kendall GS, Thayyil S (2010) Techniques for therapeutic hypothermia during transport and in hospital for perinatal asphyxial encephalopathy. Semin Fetal Neonatal Med 15: 276-286.

11. Karnatovskaia LV, Wartenberg KE2, Freeman WD3 (2014) Therapeutic hypothermia for neuroprotection: history, mechanisms, risks, and clinical applications. Neurohospitalist 4: 153-163.

12. Drury PP, Gunn ER, Bennet L, Gunn AJ (2014) Mechanisms of hypothermic neuroprotection. Clin Perinatol 41:161-175.

13. Bharadwaj SK, Bhat BV (2012) Therapeutic hypothermia using gel packs for term neonates with hypoxic ischaemic encephalopathy in resourcelimited settings: a randomized controlled trial. J Trop Pediatr 58:382-388.

14. Joy R, Pournami F, Bethou A, Bhat VB, Bobby Z (2013) Effect of therapeutic hypothermia on oxidative stress and outcome in term neonates with perinatal asphyxia: a randomized controlled trial. J Trop Pediatr 59: 17-22.
15. Gane BD, Bhat V, Rao R, Nandhakumar S, Harichandrakumar KT, et al. (2014) Effect of therapeutic hypothermia on DNA damage and neurodevelopmental outcome among term neonates with perinatal asphyxia: a randomized controlled trial. J Trop Pediatr 60: 134-140.

16. Thomas N, George KC, Sridhar S, Kumar M, Kuruvilla KA, et al. (2011) Whole body cooling in newborn infants with perinatal asphyxial encephalopathy in a low resource setting: a feasibility trial. Indian Pediatr 48: 445-451.

17. Thomas N, Rebekah G, Sridhar S, Kumar M, Kuruvilla KA, et al. (2012) Can skin temperature replace rectal temperature monitoring in babies undergoing therapeutic hypothermia in low-resource settings? Acta Paediatr 101: 564-567.

18. Thayyil S, Shankaran S, Cowan F, Ayer M, Price D, et al. (2011) Brain injury following whole body cooling after neonatal encephalopathy in a South Indian neonatal unit. Pediatr Res 70:33.

19. Bhat MA (2006) Re: Therapeutic hypothermia following perinatal asphyxia. Arch Dis Child Fetal Neonatal Ed 91: F464.

20. Jacobs SE, Berg M, Hunt R, Tarnow-Mordi WO, Inder TE, et al. (2013) Cooling for newborns with hypoxic ischemic encephalopathy. Cochrane Database Syst Rev 1.

21. Bhat BV, Adhisivam B (2014) Therapeutic cooling for perinatal asphyxiaIndian experience. Indian J Pediatr 81: 585-591.

22. Kim JJ, Buchbinder N, Ammanuel S, Kim R, Moore E, et al. (2013) Costeffective therapeutic hypothermia treatment device for hypoxic ischemic encephalopathy. Med Devices (Auckl) 1-10.

23. Iwata S, Iwata O, Olson L, Kapetanakis A, Kato T, et al. (2009) Therapeutic hypothermia can be induced and maintained using either commercial water bottles or a "phase changing material" mattress in a newborn piglet model. Arch Dis Child. 94: 387-391. 